\title{
DARI ENDE UNTUK INDONESIA: LAWATAN SEJARAH DAERAH SEBAGAI SUMBER BELAJAR BAGI GENERASI MUDA
}

\author{
Yohanes Yakobus Werang Kean \\ Prodi Pendidikan Sejarah FKIP Universitas Flores \\ E-mail: annokean@gmail.com \\ Yosef Dentis \\ Prodi Pendidikan Sejarah FKIP Universitas Flores \\ Damianus Rikardo Sumbi Wasa \\ Prodi Pendidikan Sejarah FKIP Universitas Flores \\ Email: rikardowasa@gmail.com
}

\begin{abstract}
Abstrak
Melemahnya rasa memiliki sejarah, belajar dari sejarah, dan kurangnya perhatian terhadap pengetahuan keberadaan objek-objek sejarah adalah rangkaian permasalahan kesejarahan dikalangan generasi muda. Lawatan Sejarah Daerah merupakan momentum yang sangat baik untuk merajut simpul-simpul kesejarahan. Merajut ingatan kolektif bangsa melalui penanaman nilai-nilai sejarah kepada generasi muda lewat belajar langsung dari sumber-sumber sejarah yang ada di daerahnya. Inspirasi atas prestasi dan sumbangsih dari melawat ke situs-situs bersejarah adalah merawat memori generasi muda, membela dan memperjuangkan harapan-harapan yang baik bagi genarasi muda, dan terus memperjuangkannya pembelajaran sejarah yang aktif, kreatif, inovatif dan menyenangkan. Suatu visi dari pembelajaran sejarah yang diusahakan secara sadar bukan hanya impian semata. Ende menjadi bagian penting dalam sejarah perjalanan bangsa ini, sebuah kota bersejarah bagi sang Proklamator, Ir. Soekarno. Tempat dimana beliau merenungkan Pancasila, bergaul dan mengambil nilai-nilai dari kearifan lokal masyarakat Ende itu sendiri. Melalui Lawatan Sejarah daerah ini, bermuara pada belajar dari sejarah dalam konteks penanaman nilai-nilai sejarah itu sendiri.
\end{abstract}

Kata kunci: Sumber Belajar, Situs Sejarah, Pembelajaran Sejarah.

\begin{abstract}
Weakness in having a history, learning from history, and lack of attention to the knowledge of the existence of historical objects are a series of historical problems among the younger generation. Regional History Trip is a very good momentum to knit historical nodes. Weaving the collective memories of the nation through the planting of historical values to the young generation through learning directly from the historical sources in the region. Inspiration for the achievements and contributions of visiting historical sites is taking care of the memory of the young generation, defending and fighting for hopes that are good for young generation, and continuing to fight for active, creative, innovative and fun history learning. A vision of historical learning that is consciously worked out is not just a dream. Ende is an important part in the history of this nation's journey, a historic city for the Proclamator, Ir. Soekarno. The place where he reflected on Pancasila, socializing and taking values from the local wisdom of the Ende people themselves. Through this regional history tour, it leads to learning from history in the context of planting historical values themselves.
\end{abstract}

Keywords: Learning Resources, Historical Sites, History Learning.

\section{PENDAHULUAN}

Merawat visi, bertindak fokus pada

proses, adalah konsep pelaksanaan

Lawatan Sejarah yang lebih produktif, kesempatan melakukan pembelajaran

sejarah yang berbeda. Sejarah
merupakan mata pelajaran yang
menekankan pada pengembangan
konsep serta struktur peristiwa. Namun
sering dipandang pembelajaran sejarah 
sering dianggap hanya sebagai urutan peristiwa. Hal tersebut terjadi disebabkan karena metode pembelajaran yang digunakan guru kurang bervariatif sehingga pemahaman mengenai hakikat dibalik peristiwa sejarah kurang dapat dipahami siswa. Metode pembelajaran yang tidak variatif tentunya menimbulkan rasa jenuh dan bosan dari siswa terhadap pembelajaran yang dilakukan khususnya pada mata pelajaran sejarah. Pembelajaran dengan memanfaatkan situs sejarah sebagai sumber belajar dapat menjadi salah satu alternatif dalam mengatasi masalah metode mengajar yang monoton, sehingga pembelajaran dapat menjadi lebih menarik dan rekreatif.

Wasino (2007:19) dalam bukunya menyatakan sumber sejarah berdasarkan bentuknya dapat dibagi menjadi tiga macam yaitu sumber benda (bangunan, perkakas, senjata), sumber tertulis (dokumen), sumber lisan (hasil wawancara). Situs sejarah termasuk dalam kategori sumber benda sebab bentuk dari situs-situs sejarah yang ada di Kota Ende berupa bangunanbangunan peninggalan sejarah maupun bangunan sebagai simbol suatu peristiwa sejarah yang berkaitan dengan masa pengasingan Bung Karno di Ende dari tahun 1934-1938.

Berbicara soal sejarah berarti berbicara tentang rangkaian perkembangan peristiwa yang menyangkut kehidupan manusia diwaktu yang lampau dalam berbagai aspeknya. Kemudian apabila kita berbicara tentang pengajaran sejarah itu berarti membawa rangkaian peristiwa kehidupan manusia ke dalam kelas untuk diinformasikan dan disimak murid (Widja, 1989:95). Peristiwa masa lampau yang diangkat kembali melalui prosedur penelitian sejarah oleh ahli dianggap memiliki manfaat atau kegunaan bagi kehidupan manusia pada masa sekarang yang mempelajarinya, antara lain untuk pendidikan, memberi pengajaran (instruktif), memberi ilham (inspiratif), memberi kesenangan (rekreatif) (Wasino, 2007:10). Situs sejarah tentu memilki peran yang penting dalam pembelajaran sejarah kaitannya dengan manfaat sejarah sebagai pendidikan. Situs sejarah dapat digunakan sebagai sumber sejarah yang menyajikan berbagai fakta yang lebih dekat dengan kebenaran serta memberikan fakta yang lebih dapat dipertanggungjawabkan. Sebagai sumber sejarah, situs sejarah juga dapat membantu dalam pembelajaran sejarah, dimana melalui situs-situs sejarah dapat membantu siswa dalam memahami dan mencoba merangkai peristiwa yang terjadi di masa lampau.

Pemanfaatan situs sejarah sebagai sumber belajar sejarah dapat memberikan gambaran yang lebih nyata kepada peserta didik sehingga mereka 
diharapkan dapat memahami peristiwa sejarah secara lebih nyata, tidak hanya dalam gambaran yang masih abstrak. Pemanfaatan situs sejarah dapat dilakukan dengan berbagai cara, misalnya saja melalui film dokumenter pembelajaran mengenai situs tersebut, selain itu juga dapat dengan melakukan kunjungan langsung ke situs-situs sejarah, ataupun dengan menunjukan gambar bagian-bagian situs dan lainlain.

Melalui kegiatan melawat langsung ke situs-situs sejarah di kota Ende dan dari uraian di atas dapat disimpulkan bahwa semua aspek yang ada dalam lingkungan yang dapat digunakan sebagai sumber belajar, harus dimanfaatkan secara optimal sebagai pendukung keberhasilan pendidikan. Situs sejarah merupakan salah satu bagian dari lingkungan sekitar yang memiliki potensi sebagai sumber belajar. Ende sebagai salah satu kabupaten yang memiliki beberapa situs sejarah seharusnya mampu memanfaatkan potensi tersebut secara efektif untuk mendukung peningkatan kualitas pembelajaran sejarah generasi muda.

\section{METODE PENELITIAN}

Penelitian ini menggunakan pendekatan kualitatif yaitu suatu metode yang digunakan sebagai penelitian awal untuk mengetahui kondisi kelompok sasaran atau mengetahui fenomena yang akan diteliti lebih dalam (Dewanto, 2005:64). Penulisan kualitatif menurut Gorman \& Clayton yang dikutip oleh Septiawan Santana K (2007:28) melaporkan meaning of event dari apa yang diamati penulis, berisi amatan berbagai kejadian dan interaksi yang diamati langsung penulis dari tempat kejadian. Peneliti terlibat secara partisipasif di dalam observasinya. Penelitian ini akan menghasilkan data deskriptif berupa kata-kata mengenai efektifitas pemanfaatan situs sejarah di kota Ende sebagai sumber belajar sejarah dalam usaha rancang bangun memori kolektif generasi muda.

Bogdan dan Taylor dalam Moleong (2004) mendefinisikan metodologi kualitatif sebagai prosedur penelitian yang menghasilkan data deskriptif berupa kata-kata tertulis atau lisan dari orang-orang dan perilaku yang dapat diamati. Pendekatan ini diarahkan pada latar dan individu secara holistik.Dalam hal ini individu atau organisasi tidak boleh diisolasikan kedalam variabel atau hipotesis, tetapi perlu memandangnya sebagai bagian dari suatu keutuhan. Sedangkan Kirk dan Miller sebagaimana dikutip oleh Lexy Moleong (2004:3) mendefinisikan penelitian kualitatif sebagai tradisi tertentu dalam ilmu pengetahuan sosial yang secara fundamental tergantung pada pengamatan pada manusia dalam 
kawasannya sendiri dan berhubungan dengan orang-orang tersebut dalam bahasanya dan dalam peristilahannya.

Data yang diperoleh berasal dari observasi, wawancara dan kajian pustaka yang nantinya akan disajikan dalam bentuk paragraf diskriptif dan dianalisis menggunakan teknik analisis interaktif mengenai efektifitas pemanfaatan situs sejarah di kota Ende sebagai sumber belajar.

\section{SUMBER BELAJAR}

Istilah belajar sudah sangat akrab dengan kehidupan kita sehari-hari. Belajar merupakan kegiatan yang terjadi pada semua orang tanpa mengenal batas usia dan berlangsung seumur hidup. Belajar merupakan usaha yang dilakukan seseorang melalui interaksi dengan lingkungan untuk merubah perilakunya.

Dengan demikian hasil dari belajar adalah berupa perubahan perilaku seseorang kearah yang positif. Dalam upaya melakukan proses belajar, tentunya dibutuhkan suatu hal yang dapat membantu proses belajar tersebut agar dapar berjalan sebagaimana yang diharapkan yaitu yang disebut sebagai sumber belajar.

Secara sederhana sumber belajar dapat dirumuskan sebagai segala sesuatu yang dapat memberikan kemudahan kepada peserta didik dalam memperoleh sejumlah informasi, pengetahuan, pengalaman dan ketrampilan dalam proses belajar mengajar (Mulyasa, 2003:48). Selain itu, sumber belajar dapat pula diartikan sebagai segala macam yang ada diluar diri peserta didik yang memungkinkan (membuahkan) terjadinya proses belajar (Rohani, 1997:102). Menurut Asosiasi Teknologi Komunikasi Pendidikan (AECT) sumber belajar adalah semua sumber (baik berupa data, orang, atau benda) yang dapat digunakan untuk member fasilitas (kemudahan) belajar bagi siswa (Sudjarwo, 1989:141).

Sumber belajar itu meliputi pesan, orang, bahan, peralatan, teknik, dan lingkungan/latar. Pesan adalah ajaran atau informasi yang akan disampaikan oleh komponen belajar lain, yang dapat berupa ide, fakta, ajaran, nilai dan data. Dalam sistem pembelajaran, maka pesan ini berupa seluruh mata pelajaran yang disampaikan kepada siswa. Orang adalah manusia yang berperan sebagai pencari, penyimpan, pengolah dan penyaji pesan. Misalnya saja guru, dosen, instruktur, tenaga ahli dan sebagainya. Bahan merupakan perangkat lunak (software) yang mengandung pesan belajar, yang biasanya disajikan menggunakan peralatan tertentu. Teknik yaitu prosedur atau langkah-langkah tertentu yang disiapkan untuk menggunakan bahan, alat, lingkungan dan orang untuk menyampaikan pesan. Sedangkan lingkungan/latar adalah situasi di 
sekitar terjadinya proses belajar mengajar dimana pembelajar menerima pesan.

Ditinjau dari tipe dan asal-usulnya, sumber belajar dapat dibedakan menjadi dua:

a. Sumber belajar yang dirancang (learning resources by design) yaitu sumber belajar yang sengaja dibuat untuk tujuan pembelajaran. Sumber belajar seperti ini sering disebut sebagai bahan pembelajaran. Contohnya adalah buku pelajaran, modul, program audio dal lain-lain.

b. Sumber belajar yang sudah tersedia dan tinggal dimanfaatkan (learning resources by utilization), yaitu sumber belajar yang tidak secara khusus dirancang untuk keperluan pembelajaran, namun dapat ditemukan, dipilih dan dimanfaatkanuntuk keperluan pembelajaran. Termasuk didalamnya yaitu museum dan situs sejarah. Keduanya termasuk sebagai sumber belajar yang sudah tersedia dan tinggal dimanfaatkan untuk keperluan pembelajaran.

Sumber belajar memiliki beberapa fungsi dalam kaitannya sebagai media belajar, antara lain:

a. Meningkatkan produktivitas pembelajaran dengan jalan: 1) mempercepat laju belajar dan membantu guru untuk menggunakan waktu secara lebih baik dan 2) mengurangi beban guru dalam menyajikan informasi, sehingga dapat lebih banyak membina dan mengembangkan semangat.

b. Memberikan kemungkinan pembelajaran yang lebih individual, dengan cara:

1) mengurangi kontrol guru yang kaku dan tradisional 2) memberikan kesempatan bagi siswa untuk berkembang sesuai dengan kemampuannnya.

c. Memberikan dasar yang lebih ilmiah terhadap pembelajaran dengan cara: 1) perancangan program pembelajaran yang lebih sistematis; dan 2) pengembangan bahan pengajaran yang dilandasi oleh penelitian.

d. Lebih memantapkan pembelajaran, dengan jalan: 1) meningkatkan kemampuan sumber belajar; 2) penyajian informasi dan bahan secara lebih kongkrit.

e. Memungkinkan belajar secara seketika, yaitu: 1) mengurangi kesenjangan antara pembelajaran yang bersifat verbal dan abstrak dengan realitas yang sifatnya kongkrit; 2) memberikan pengetahuan yang sifatnya langsung.

f. Memungkinkan penyajian pembelajaran yang lebih luas, dengan menyajikan informasi yang mampu menembus batas geografis. (http://akhmadsudrajat.wordpress.C 
om/2008/04/15/sumber-belajar-

untuk-

mengefektifkan-pembelajaran-

siswa/).

Sebagaimana disebutkan oleh I

Gde Widja (1989: 61-68) sumber belajar dalam pembelajaran sejarah yang terpenting yaitu:

a. Peninggalan sejarah seperti jejak tertulis (dokumen) jejak benda dan jejak lisan. Jejak benda seperti candi, monumen, museum, jejak lisan pelaku sejarah, tokoh pejuang.

b. Sumber belajar yang sudah tersedia yang tinggal memanfaatkan untuk pengajaran sejarah meliputi antara lain:

1) Monumen

Monumen didirikan untuk menandai dan mengenang suatu peristiwa bersejarah pada suatu tempat. Dalam monumen digambarkan jalan peristiwa dalam bentuk relief

2) Perpustakaan

Perpustakaan sebagai penyimpanan koleksi bahan pustaka yang diproses secara sistematis agar cepat dan mudah melayani kebutuhan pemakaian jasa perpustakaan koleksi perpustakaan menyangkut buku sejarah.

3) Sumber manusia

Pelaku sejarah atau tokoh pejuang maupun sejarawan serta seorang guru sejarah merupakan diantara sumber belajar sejarah

4) Situs sejarah

Peninggalan sejarah seperti situs purbakala, candi, masjid, kraton, makam, tokoh sjarah maupun sumber sejarah. Kompleks percandian menunujukan bahwa wilayah tersebut merupakan pusat pengembangan

dan kegiatan pada masa lalu atau jaman dahulu. Gedung sejarah menunjukan pula bahwa disitu pernah ada pusat aktifitas suatu masyarakat. Masjid bersejarah mengisyaratkan bahwa disitu juga pernah ada pusat pengembangan dan kegiatan para tokoh utama atau wali dan lain-lain dalam mendalami agama Islam. Kraton menunjukan sebagai pusat pemerintahan dari suatu kerajaan.

5) Museum

Merupakan tempat menyimpan benda-benda peninggalan sejarah.

6) Masyarakat Masyarakat sebagai sumber belajar menyimpan pesan-pesan sejarah yang berupa legenda, cerita rakyat, kisah-kisah kepahlawanan maupun pesan kebudayaan lainnya.

\section{PEMBELAJARAN SEJARAH}


Sejarah adalah gambaran masa lalu tentang manusia dan sekitarnya sebagai mahluk sosial yang disusun secara ilmiah dan lengkap, meliputi urutan fakta masa tersebut dengan tafsiran dan penjelasan yang member pengertian tentang apa yang telah berlalu itu (Gazalba, 1981: 13). Kata Inggris history (sejarah) berasal dari kata benda Yunani istoria yang berarti ilmu. Menurut definisi yang paling umum, kata history kini berarti "masa lampau umat manusia" (Gottschalk, 1985:27). Sedangkan sejarah dalam bahasa Jerman yaitu geschichte yang berasal dari kata geschehen yang berarti terjadi.

Geschichte sendiri memiliki arti sesuatu yang telah terjadi. Kedua kata tersebut memberikan arti yang lebih kompleks tentang sejarah, yaitu sesuatu yang telah terjadi pada waktu lampau dalam kehidupan manusia. Sejarah tidak dapat dipisahkan dari kehidupan manusia dan berkembang sesuai dengan perkembangan kehidupan manusia.

Sejarah dalam fungsinya bukan hanya sekedar mengingat masa lampau tapi sejarah adalah cerminan aktivitas kehidupan manusia dimasa lampau pada masa kini. Sejarah ibarat kompas bagi kehidupan atau dasar bagi seorang pilot untuk mengambil keputusan, karena sejarah adalah kristalisasi dari semua pengetahuan, semua ilmu dan semua yang telah dipelajari sejak manusia ada. Kondisi yang demikian, memungkinkan sejarah untuk mengangkat nilai-nilai universal yang terkandung dari setiap bentuk budaya manusia. Dengan demikian pendidikan sejarah tidak hanya diarahkan untuk menanamkan pemahaman masa lampau hingga masa kini, menumbuhkan rasa tentang adanya perkembangan masyarakat kebangsaan dan cinta tanah air serta rasa bangga sebagai warga Indonesia dan memperluas wawasan hubungan masyarakat antar bangsa di dunia. (Depdikbud RI, 1998:80-83).

\section{SITUS SEJARAH SEBAGAI SUMBER}

\section{BELAJAR}

Menurut Kamus Besar Bahasa Indonesia (KBBI) situs sejarah merupakan daerah dimana ditemukan benda-benda purbakala (Tim Penyusun Kamus Pusat Bahasa, 2007:1078). Situs sejarah memiliki berbagai kegunaan. Selain sebagai penelitian arkeologis, situs sejarah dapat pula dimanfaatkan sebagai tempat pariwisata budaya serta sebagai sumber belajar siswa dimana siswa dapat berlatih menganalisis peristiwa sejarah berdasarkan bukti sejarah yang berupa situs sejarah tersebut. Situs sejarah yang dimanfaatkan sebagai sumber belajar sejarah, secara tidak langsung dapat meningkatkan kulitas pembelajaran sejarah. Ketika situs sejarah telah dimanfaatkan sebagai sumber belajar sejarah, maka situs sejarah tersebut 
akan menjadi alternatif media sumber pembelajaran yang strategis untuk meningkatkan minat dan pemahaman siswa mengenai materi yang berhubungan dengan situs sejarah tersebut sehingga secara tidak langsung dapat meningkatkan kualitas pembelajaran sejarah.

Situs sejarah dapat pula digunakan sebagai sarana bagi siswa untuk mencoba menganalisis peristiwa masa lalu dan merangkainya menjadi sebuah cerita utuh. Peristiwa sejarah tidak mungkin dapat dihadirkan secara nyata dalam pembelajaran sejarah, sebab sebagai peristiwa, sejarah memiliki sifat unik. Maksud dari sejarah sebagai peristiwa yang unik yaitu peristiwa sejarah hanya terjadi sekali dan tidak dapat terulang persis sama untuk kedua kalinya sehingga peristiwa sejarah tidak akan mungkin dapat dihadirkan dalam kelas. Maka dari itu keberadaan situs sejarah dapat digunakan oleh guru sebagai sumber belajar untuk menghadirkan peristiwa sejarah tersebut dalam pikiran siswa.

Sejarah akan menjadi mata pelajaran yang membosankan manakala dalam proses pembelajarannya tidak dilakukan dengan metode yang menarik atau dengan kata lain pembelajaran yang dilakukan guru sangat monoton. Situs sejarah dapat digunakan sebagai alternatif untuk mengatasi hal tersebut. Sebab dalam hal ini siswa akan mengalami proses pembelajaran yang lebih berorientasi pada mereka dan mereka dituntut untuk memvisualisasikan imajinasi mereka berkaitan dengan situs sejarah sebagai sumber belajar mereka. Hal tersebut tentunya akan meningkatkan peran dan keaktifan siswa dalam proses pembelajaran sehingga diharapkan siswa akan lebih tertarik belajar sejarah dengan sumber belajar yang nyata dan lebih dekat dengan kebenaran.

\section{HASIL DAN PEMBAHASAN}

\section{Hasil Penelitian}

1. Situs-Situs Sejarah yang ada di Kota Ende dan dikunjungi dalam lawatan Sejarah daerah: Pura Woloare sebagai tempat meditasi Bung Karno, Rumah Pengasingan Bung Karno, Makam Ibu Amsi (Ibu Mertua Bung Karno), Taman Renungan Pancasila.

2. Kondisi situs-situs sejarah di kota Ende dalam kaitannya pemanfaatan situs tersebut sebagai sumber belajar sudah layak untuk dijadikan sebagai sumber belajar. Situs-situs sejarah yang ada di kota Ende yang sangat terkait dengan perjalanan sejarah Bangsa terutama Soekarno dan masa pembuangannya memiliki nilai historis yang tinggi dan materi yang terkandung di dalam situs-situs tersebut sesuai dengan materi dalam pembelajaran sejarah yang berlaku. 
3. Bentuk pemanfaatan situs sejarah sebagai sumber belajar yang sudah dilaksanakan berbeda-beda di setiap sekolah tergantung dari faktorfaktor pendukung pembelajaran dari masing-masing sekolah.

4. Kendala yang dihadapi guru sejarah dalam pelaksanaan pemanfaatan situs sejarah yang ada di kota Ende berbeda-beda tergantung kepada bentuk Pemanfaatan situs sejarah itu sendiri dan faktor-faktor pendukung pembelajaran dari masing-masing sekolah.

5. Upaya yang dilakukan oleh guru sejarah untuk mengatasi kendala yang dihadapi bervariasi sesuai dengan kendala yang dihadapi.

6. Efektivitas pemanfaatan situs sejarah di kota Ende sebagai sumber belajar dapat ditinjau dari dua hal yaitu dilihat dari proses pemahaman generasi muda dan hasil yang dicapai di sekolahnya. Ditinjau dari proses pemahaman siswa, masing-masing sekolah berbeda dalam tingkat keefektifannya.

\section{Pembahasan}

Kota Ende yang dikenal sebagai Kota Pelajar baik di seluruh Pulau Flores maupun Provinsi Nusa Tenggara Timur terdiri dari begitu banyak sekolah. Masing-masing sekolah memiliki karakteristik dan kualitas yang berbedabeda sehingga dalam pelaksanaan pembelajaran sejarah yang dilakukan pun tidak sama. Termasuk didalamnya pembelajaran dengan memanfaatkan situs sejarah yang ada di kota Ende. Dalam kaitannya dengan hal tersebut, berdasarkan pra penelitian yang dilakukan tidak semua Sekolah dan Perguruan Tinggi di Kota Ende sudah memanfaatkan situs-situs sejarah yang ada di kota Ende sebagai sumber belajar.

Bentuk-bentuk pemanfaatan situs sejarah di Kota Ende sebagai sumber belajar sejarah Generasi Muda yang sudah dilakukan adalah sebagai berikut:

a. Pemanfaatan situs-situs sejarah di kota Ende melalui media gambar dan film. Situs-situs sejarah yang ada di kota Ende dapat dimanfaatkan melalui berbagai media pembelajaran yang salah satunya yaitu media gambar dan film

b. Pemanfaatan situs-situs sejarah di kota Ende melalui penelitian Sejarah Metode penelitian sejarah adalah penelitian yang dilakukan dengan beberapa prosedur penelitian sejarah yang terdiri dari beberapa tahap, antara lain pengumpulan sumber-sumber sejarah, kritik sumber, interpretasi sumber dan yang terakhir adalah historiografi. Hariyono dalam Isjoni (2007:82) menyatakan bahwa pembelajaran dengan menggunakan metode penelitian sejarah memberikan pengalaman dalam mengumpulkan, mengorganisasikan, dan mengklasifikasi 
data yang luas. Penelitian sejarah mengajarkan kepada murid bagaimana mencari informasi yang relevan, menggunakan wawasan sejarah untuk memecahkan masalah, atau mengkomunikasikan hasil belajarnya kepada orang lain. Metode ini digunakan oleh Program Studi Pendidikan Sejarah Universitas Flores. Pembelajaran dengan memanfaatkan situs sejarah sebagai sumber belajar melalui penelitian sejarah ini sudah dilakukan dimana siswa diberi tugas kelompok diluar jam pelajaran untuk meneliti peninggalanpeninggalan sejarah yang ada di lingkungan mereka kemudian hasilnya dikumpulkan dalam bentuk makalah. Masing- masing kelompok siswa dituntut untuk mampu melaksanakan prosedur penelitian sejarah, pertama yaitu dengan sumber-sumber sejarah baik itu sumber primer yaitu mencari pelaku yang menjadi saksi hidup dalam peristiwa sejarah yang mereka gali maupun sumber sekunder baik berupa buku, surat kabar yang relevan maupun saksi (bukan pelaku) yang mengertimengenai peritiwa sejarah yang sedang mereka gali. Prosedur selanjutnya yang dituntut untuk dapat dilakukan oleh siswa adalah meneliti keaslian data yang mereka peroleh. Pada akhirnya mereka dituntut untuk menginterpretasikan data yang mereka peroleh sebelum kemudian mereka tuangkan dalam bentuk tulisan.
Kendala yang Dihadapi Guru atau Dosen dalam Upaya Memanfaatan Situs-situs Sejarah di Ende sebagai Sumber Belajar untuk Pembelajaran Sejarah pada Generasi Muda di Kabupaten Ende:

a. Lokasi yang sulit dijangkau Kendala yang berupa sulitnya lokasi situs sejarah untuk dijangkau hanya berlaku untuk situs sejarah Pura Woloare. Hal tersebut dapat terjadi mengingat yang memiliki akses jalan yang sulit untuk dijangkau, sedangkan untuk situs sejarah yang lain sebagian besar terletak di tepi jalan raya sehingga akses untuk menuju lokasinya mudah dijangkau.

b. Keterbatasan Waktu

Hal lain yang menjadi kendala dalam melaksanakan pembelajaran dengan memanfaatkan situs sejarah sebagai sumber belajar yaitu adanya keterbatasan waktu dalam alokasi pembelajaran sejarah. Sesuai peraturan yang tertera dalam standar isi yang mengatur pembagian jam pelajaran untuk masing-masing pelajaran, untuk mata pelajaran sejarah alokasi waktunya.

c. Faktor intern Generasi Muda

Masing-masing generasi muda dalam kegaiatan ini dari tingkatan SMA hingga perguruan tinggi tentu memiliki kondisi yang berbeda-beda dalam semua aspek. Hal tersebut membuat guru atau Dosen harus lebih jeli dalam melaksanakan pembelajaran dengan lebih 
memperhatikan kondisi dari masingmasing siswanya. Guru atau Dosen tentunya tidak boleh menggeneralisasikan mereka dalam satu pola pembelajaran yang sama tanpa memperhatikan perbedaan kondisi masing-masing peserta didik. Jika ingin melaksanakan pembelajaran dengan pola yang sama untuk peserta didik, tentunya harus disesuaikan dengan kondisi dari seluruh peserta didiknya agar tidak terjadi semacam kesenjangan dalam pelaksanaan pembelajarannya.

Dalam proses pembelajaran yang dilakukan, tentunya akan selalu terdapat kendala yang menjadi hambatan bagi guru untuk melaksanakan pembelajaran yang ideal seperti yang mereka harapkan. Komponen-komponen yang ada dalam pembelajaran tidak selalu bisa sesuai dengan harapan guru sehingga seringkali terjadi proses pembelajaran yang tidak sesuai harapan. Banyak kendala-kendala yang muncul dalam proses pembelajaran yang mereka lakukan sehingga untuk tetap dapat melaksanakan pembelajaran yang sesuai dengan harapan dan tujuan yang sudah ditetapkan, perlu adanya tindak lanjut atau upaya dalam mengatasi kendala-kendala tersebut. Usaha mencari solusi untuk dapat melaksanakan pembelajaran sesuai yang diharapkan, berlaku pula bagi pembelajaran sejarah khususnya dalam hal ini pembelajaran sejarah dengan memanfaatkan situs sejarah sebagai sumber belajar. Pemanfaatan situs sejarah sebagai sumber belajar seperti yang sudah dijelaskan sebelumnya menemui banyak kendala yang menjadi halangan bagi guru sejarah. Kreatifitas dari Guru atau Dosen menjadi kunci untuk mengatasi kendala-kendala di atas.

\section{KESIMPULAN}

Situs sejarah merupakan salah satu bagian dari lingkungan sekitar yang memiliki potensi sebagai sumber belajar. Ende sebagai salah satu kabupaten yang memiliki beberapa situs sejarah seharusnya mampu memanfaatkan potensi tersebut secara efektif melalui kegiatan lawatan sejarah untuk mendukung peningkatan kualitas pembelajaran sejarah dari tingkat SDSMA maupun perguruan tinggi. Upaya yang dilakukan oleh guru sejarah untuk mengatasi kendala yang dihadapi bervariasi sesuai dengan kendala yang dihadapi, Efektivitas pemanfaatan situs sejarah di kota Ende sebagai sumber belajar dapat ditinjau dari dua hal yaitu dilihat dari proses pemahaman generasi muda dan hasil yang dicapai di sekolahnya. Ditinjau dari proses pemahaman siswa, masing-masing sekolah berbeda dalam tingkat keefektifannya

\section{DAFTAR PUSTAKA}

Depdikbud RI. (1998). Simposium Pengajaran Sejarah (kumpulan 
Makalah Diskusi). Jakarta: CV Eka Dharma.

Dewanto, Philip. (2005). Metodologi Penelitian. Semarang: UNNES Press.

Fowler, Bridget. (2007). The Obituary as Collective Memory London: Routledge.

Gazalba, Sidi. (1981). Pengantar Sejarah sebagai Ilmu. Bandung: Bharata Karya Aksara.

Gottschalk, Louis. (1985). Mengerti Sejarah, Pengantar Metode Sejarah. Terjemahan Nugroho Noto Susanto. Jakarta: UI Press

Miles, Mathew B. dan A. Michael Huberman. (2007). Analisis Data Kualitatif. Jakarta: UI Press.

Moleong, Lexy. (2004). Metodologi Penelitian Kualitatif. Bandung: PT Remaja Rosdakarya.

Mulyasa. (2003). Kurikulum berbasis kompetensi. Bandung: PT Remaja Rosdakarya.

Mulyasa. (2006). Kurikulum Tingkat Satuan Pendidikan. Bandung: PT Remaja Rosdakarya.

Peraturan Menteri Pendidikan Nasional Nomor 22 Tahun 2006 tentang Standar Isi untuk Satuan Pendidikan Dasar dan Menengah.

Peraturan Pemerintah Nomor 19 Tahun 2005 tentang Standar Nasional Pendidikan. Rohani, Ahmad. (1997). Media Internasional Edukatif. Jakarta: PT Rineka cipta.

Sadiman, Arif dkk. (2008). Media Pendidikan: Pengertian, Pengembangan, dan Pemanfaatannya. Jakarta: PT Raja Grafindo Persada.
Santana K, Septiawan. (2007). Menulis Ilmiah Metode Penelitian Kualitatif. Bandung: yayasan Obor Indonesia.

Sudjarwa. (1989). Beberapa Aspek Pengembangan Sumber Belajar. Jakarta: PT Mediatama sarana perkasa.

Sudrajat, Ahmad. (2008). Sumber Belajar untuk Mengefektifkan Pembelajaran

Siswa.http: / /akhmadsudrajat.wor dpress.com/2008/04/15/sumberbelajar-untuk-mengefektifkanpembelajaran-siswa/artikel. (31 Mei 2011)

Tim Penyusun Kamus Pusat Bahasa. (2007). Kamus Besar Bahasa Indonesia. Jakarta: Balai Pustaka

Wasino. (2007). Dari Riset hingga Tulisan Sejarah. Semarang: UNNES Press.

Widja, I Gede. (1989). Dasar-dasar pengembangan strategi serta metode pengajaran sejarah. Jakarta: PT Rineka cipta.

Widja, I Gede. (1989). Sejarah Lokal Suatu Perspektif Dalam Pengajaran Sejarah. Jakarta: Depdikbud. 